\title{
Impact of water input on plankton temporal dynamics from a managed shallow saline lake
}

\author{
María Belén Alfonso ${ }^{1, *}$, Josefina Zunino ${ }^{1}$ and María Cintia Piccolo ${ }^{1,2}$ \\ ${ }^{1}$ Instituto Argentino de Oceanografía (IADO), Universidad Nacional del Sur (UNS)-CONICET, Florida 8000, Bahía Blanca, Argentina \\ ${ }^{2}$ Departamento de Geografía y Turismo, Universidad Nacional del Sur, 12 de Octubre 1198, Bahía Blanca, Buenos Aires, Argentina
}

Received: 21 April 2017; Accepted: 11 September 2017

\begin{abstract}
La Salada is a shallow saline lake located in the SW of the Pampas subject to significant water management, so the primary objective was to assess whether the water input and physicochemical parameters have an impact on the plankton assemblages over a two year period (2013-dry and 2014-wet). The plankton community structure and physicochemical variables showed substantial changes over the study period. La Salada hosted a plankton community characterized by low diversity and small sized organisms. The nanoplanktonic fraction organisms $(2-20 \mu \mathrm{m})$ dominate the phytoplankton community. Ochromonas sp. showed the maximum abundance throughout the whole study period. The zooplankton community was dominated by rotifers, with a lack of cladocerans. Halotolerant species, e.g. the rotifer Brachionus plicatilis and the cyclopod Apocyclops sp. were the main species. The seasonal temperature and conductivity dynamics influence the plankton abundance dynamics in La Salada. The increment of nutrients and decrease of conductivity caused by the water input led to an increase in plankton biomass and shaped its composition. These findings emphasize that interactions between plankton, salinity, and nutrients are sensitive to the water input and they improve the understanding of the impact of adequate management decisions.
\end{abstract}

Keywords: phytoplankton / zooplankton / climate variability / water management / water level

\section{Introduction}

Shallow lakes are the most abundant lake types globally (Downing et al., 2006). The water level in shallow lakes fluctuates naturally intra- and inter-annually depending mostly on the regional climatic conditions and human activities (Gafny and Gasith, 1999; Beklioglu et al., 2007). The endorheic shallow lakes have a high surface/depth ratio and polymictic condition, therefore hydrological fluctuations intensify the changes in its limnological conditions. Any significant variation in water level, whether spatial or temporal, will affect not only the physical environment of the lake but also the biological communities through ecological processes (Leira and Cantonati, 2008). Worldwide, temperature and rainfall patterns have notable fluctuations in recent decades and are predicted to vary even more in the future. These changes will magnify the seasonal and multiannual amplitude of water level, and in turn, it will create hydrological stresses particularly in shallow lakes (IPCC, 2014). Natural water level variations are necessary for the

\footnotetext{
*Corresponding author: mbalfonso@iado-conicet.gob.ar
}

survival of many species, as a guarantee for both productivity and biodiversity (Gafny et al., 1992; Gafny and Gasith, 1999). Only extreme floods and droughts have adverse effects for both biota and man (Sparks et al., 1998). These often represent one of the greatest impacts on the development of lake ecosystems, particularly on the trophic state, underwater light climate, plankton dynamics and littoral development (Moos et al., 2005; Laird and Cumming, 2008; Wolin and Stone, 2010). They also alter the lake's morphometry and directly affect sedimentation, resuspension, and biogeochemical dynamics (Bohn et al., 2016).

Plankton is an important indicator of the structure and function of lake ecosystems and their ecological status (Jeppesen et al., 2011). Particularly, in shallow saline lakes, the water level fluctuations coupled with salinity may affect the trophic structure when the diversity of aquatic species declines as osmotic tolerances are exceeded with increasing salinity (Vignatti et al., 2012a,b; Barnes and Wurtsbaugh, 2015; Jeppesen et al., 2015). In addition, other factors, such as habitat permanence, water management, inflows of fresh water (enriched by nutrients by anthropogenic use) and trophic interactions alter the structure of aquatic communities in saline lakes (Jeppesen et al., 1994; Barker et al., 2008; Larson and Belovsky, 2013; Stenger-Kovács et al., 2014). Species richness 


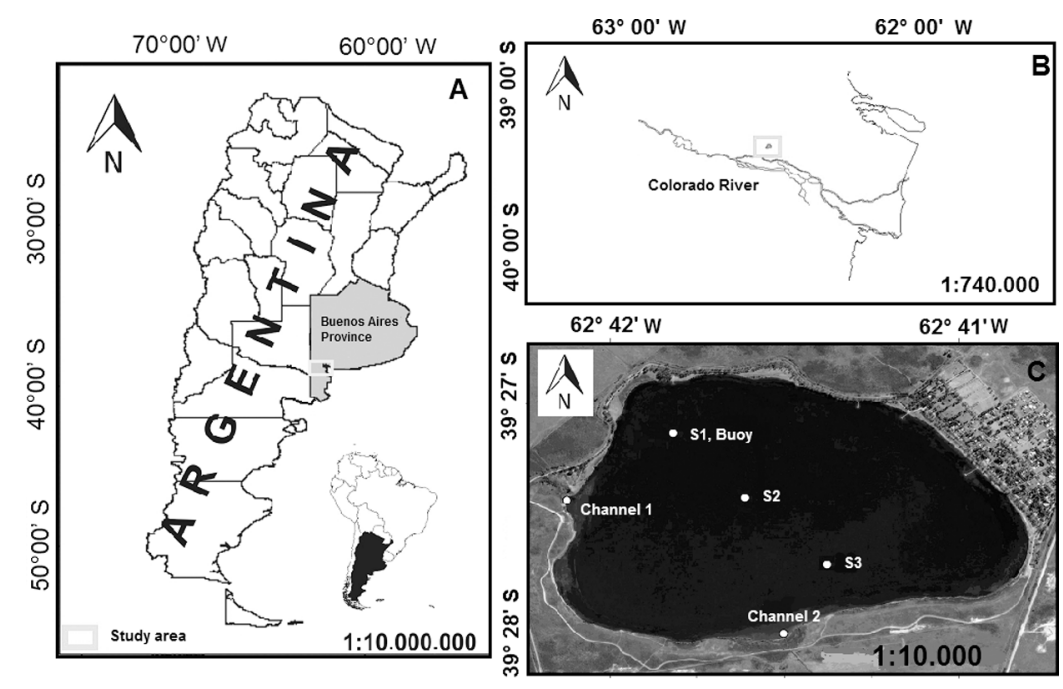

Fig. 1. Location map of (a) the study area, (b) La Salada lake and Colorado river and (c) La Salada lake.

decreased with increasing salinity and increased with nutrient enrichment in saline lakes, demonstrating the importance of nutrients supply (Larson and Belovsky, 2013).

Shallow lakes located in the Pampas, an extensive and fertile plain in Argentina (Labraga et al., 2011), are mostly polymictic and present high nutrient levels, ranging from eutrophic to highly hypertrophic (Quirós and Drago, 1999). The Pampas is characterized by the occurrence of long periods of drought and floods, which affect the water availability, the productivity of agricultural systems and other human activities (Aliaga et al., 2017). Also, water stress is the result of climatic variability in conjunction with anthropogenic pressures. Increases or decreases in precipitation and runoff may create extreme events, floods or droughts, respectively and there is evidence that these events are increasing in frequency (Gleick, 2003; Mirza, 2003).

In most lakes, the relatively short period covered by data monitoring also creates difficulties in understanding how plankton communities are affected by environmental parameters. Nevertheless, advances in sensor technology provide the opportunity for monitoring many key ecological variables at short temporal scales (Staehr et al., 2010; Laas et al., 2012; Alfonso et al., 2015). La Salada has an outstanding water management program. The presence of a buoy which continuously measures physicochemical parameters offers an excellent opportunity for analyzing changes in plankton dynamics caused by natural and human influenced variations in the physicochemical parameters of the lake. The effects of natural or anthropogenic water level fluctuations on plankton dynamics have been studied in many lakes around the world (Jeppesen et al., 2015; Liu et al., 2015; Debastiani-Júnior and Nogueira, 2016). However, shallow and saline lake systems in the southern hemisphere were poorly studied (Rennella and Quirós, 2006; Chaparro et al., 2016; Pilati et al., 2016) and very little research has been carried out in saline lakes with anthropogenic management (Vignatti et al., 2012a; Del Ponti et al., 2015).

Variations in salinity values are a dominant factor influencing plankton diversity in saline lakes among other physicochemical parameters (e.g. nutrient concentrations and temperature) which are also important and can interact with salinity to affect plankton communities. Also, the water level in shallow lakes fluctuates naturally and depends largely on human activities. Under the hypothesis that the water management in the lake will produce changes in the physicochemical parameters, the aim of this study was to determine how water inputs and physicochemical parameters affect the plankton community in this shallow saline lake.

\section{Materials and methods}

\subsection{Study site}

La Salada $\left(39^{\circ} 27^{\prime} \mathrm{S}, 62^{\circ} 42^{\prime} \mathrm{W}\right)$ is a shallow saline lake $(2.5 \mathrm{~m})$ located in the SW of the Pampas in Argentina (Fig. 1). It is a small polymictic lake $\left(4 \mathrm{~km}^{2}\right)$, in a region where agriculture is performed with an irrigation system. Its major affluent is a channel derived from the river Colorado, which is managed by Water Authorities. The Development Corporation of the Colorado River Valley (CORFO, for its name in Spanish) administers and enforces the irrigation regime in the area. The Water Authorities decide when and how much water enters the lake through two irrigation channels (Fig. 1c). Normally, the irrigation system gates are open each year from August 1st to May 1st. La Salada is an alkaline, mesotrophiceutrophic lake, where despite the low concentration of chlorophyll $a\left(8.6 \mu \mathrm{g} \mathrm{L}^{-1}\right)$, it presents a general net autotrophic state (Alfonso et al., 2015).

The presence of the omnivorous fish Odonthestes sp. is common in this lake (Bersain, 2012). The climate of the region is cold temperate and mostly dry, with the alternate of wet and dry cycles. Mean annual temperature values range from 14 to $20^{\circ} \mathrm{C}$. Average annual rainfall is $518 \mathrm{~mm}$, and higher precipitations typically occur during spring and summer (Scian, 2000). Wind speed above $40 \mathrm{~km} \mathrm{~h}^{-1}$ for several hours from NW is a common feature in the region (Alfonso et al., 2015). Two lake monitoring network projects carried out in Argentina (PAMPA2) and America (SAFER, IAI), include this lake, whose primary objective is to analyze the responses of the shallow lakes to climate change, land use, and other anthropogenic impacts. 

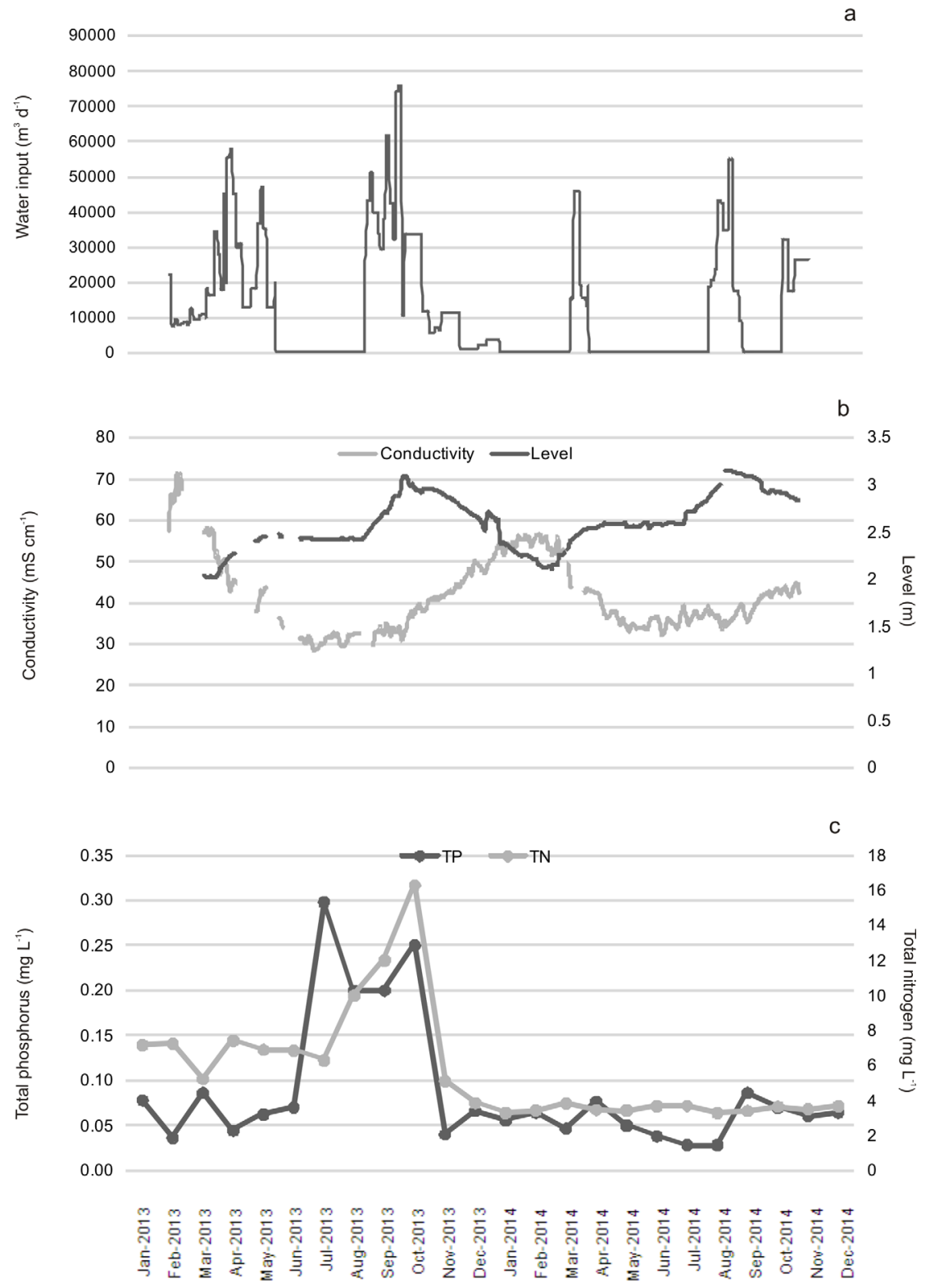

Fig. 2. (a) Total water input $\left(\mathrm{m}^{3}\right.$ day $\left.{ }^{-1}\right)$ values measured in the main channels. (b) High frequency measurements of conductivity and water level values and (c) monthly measurements of total nitrogen (TN) and total phosphorus (TP) values in La Salada during the study period.

\subsection{Environmental variables}

Monthly samples were taken from January 2013 to December 2014. Conductivity, dissolved oxygen (DO), $\mathrm{pH}$ and water temperature were measured in situ using a HORIBA U10 probe. Water samples were taken at a depth of $0.5 \mathrm{~m}$. Nutrients, such as total phosphorus (TP) and total nitrogen (TN), were estimated following APHA (1998). Total suspended solids (seston) were determined by the gravimetric method with precombusted Whatman ${ }^{\mathrm{TM}} \mathrm{GF} / \mathrm{F}$ filters. Chlorophyll $a(\mathrm{Chl} a)$ concentration was estimated by the spectrophotometric method, using 90\% acetone (Marker et al., 1980). Secchi disk depth (SDD) was used to characterize the water transparency.

In addition, continuous measurements of limnological parameters and meteorological variables were obtained from an automated set of sensors attached to a buoy every $10 \mathrm{~min}$
(Estación de Monitoreo Ambiental Costero, http://emac.iadoconicet.gob.ar/) moored at the lake's deepest point. DO, water temperature and conductivity were measured at a depth of $0.5 \mathrm{~m}$. Water level was measured from the bottom of the lake. Also, the air temperature and wind speed and direction were obtained from a meteorological station located on the buoy ( $2.10 \mathrm{~m}$ above the water surface). Measurements of the amount of water entering the lake from the channel (water input) were obtained from the Corporación de Fomento del Río Colorado (CORFO, http://corfo.gob.ar/). Historical precipitation values (1966-2014) were obtained from a nearby meteorological station within $10 \mathrm{~km}$ from La Salada (Instituto Nacional de Tecnología Agropecuaria, HilarioAscasubi, http://rian.inta. gov.ar/). To quantify precipitation anomalies the standardized precipitation index (SPI) was calculated, which classifies the intensity of dry and wet conditions (Du et al., 2013). 


\subsection{Plankton sampling and analysis}

Quantitative phytoplankton samples were collected from the surface and preserved with Lugol's iodine solution. Qualitative samples were obtained with a $17 \mu \mathrm{m}$ mesh net and fixed in $4 \%$ formaldehyde solution. The phytoplankton was counted under an inverted microscope Wild M40 (Utermöhl, 1958) and a counting error was estimated according to Venrick (1978). Phytoplankton abundances were expressed as individuals per milliliter (ind. $\mathrm{mL}^{-1}$ ). Also, biovolumes were calculated using appropriate geometric formulae (Hillebrand et al., 1999; Sun and Liu, 2003) and algal biomass was estimated assuming unit specific gravity.

Quantitative zooplankton samples were collected at three sample sites evenly distributed along the lake's longest axis (Fig. 1c). Approximately $100 \mathrm{~L}$ of water were filtered through a $47 \mu \mathrm{m}$ mesh net in three vertical hauls at each site. Samples were immediately preserved in buffered $4 \%$ formaldehyde solution. For qualitative analyses, all samples were examined under a Nikon SMZ 1500 stereoscopic microscope. For quantitative analysis, rotifers and copepod nauplii were counted under a microscope Nikon Eclipse $80 \mathrm{i}$ on $1 \mathrm{~mL}$ SedgwickRafter counting cell. The remaining crustaceans were counted in a $5 \mathrm{~mL}$ Bogorov chamber under a stereoscopic microscope. The number of aliquots was calculated according to Cassie (1971). Zooplankton abundances were expressed as individuals per liter (ind. $\mathrm{L}^{-1}$ ). Mean individual biomass was calculated as dry weight $\left(\mathrm{mg} \mathrm{L}^{-1}\right)$ using length-weight regressions (Dumont et al., 1975; Bottrell et al., 1976).

\subsection{Data analysis}

The species contributing $\geq 3 \%$ to the total abundance were used for the analysis. The non-parametric Kruskal Wallis statistic $H$ (Legendre and Legendre, 1998) was computed to test for significant differences in the plankton biomass and environmental variables between years. A Spearman correlation ranks was performed in order to identify those environmental factors that may have played the most significant role. A detrended correspondence analysis showed a linear response of the biological data; then, a Redudancy Analysis (RDA) was performed in order to analyze which of the primary environmental variables were responsible for the variation in the plankton community. The ability of environmental variables to explain the variance in species data in the RDA was tested by a Monte Carlo permutation test. Variables were considered to be significant for $p<0.05$. All analyses were performed with STATISTICA $7^{\text {क }}$, CANOCO software (Ter Braak, 1986) and InfoStat .

\section{Results}

\subsection{Environmental parameters}

La Salada lake experienced great changes during the study period associated with variations in the input of water which presented significant differences between the years $(H=16.33$; $p=0.0001)$. The amount of water that entered the lake through the river Colorado channels was twice as much in 2013 $\left(5727196.8 \mathrm{~m}^{3}\right)$ as compared with $2014\left(2500588.8 \mathrm{~m}^{3}\right)$ (Fig. 2a). Precipitation in 2013 fluctuated between 0 (June, August) and $55.7 \mathrm{~mm}$ (September), whereas in 2014 it was between 8
(January) and $92.5 \mathrm{~mm}$ (March). Significant differences in rainfall were found between the years $(H=4.08 ; p<0.05)$ 2014 being the year with the highest precipitation. Based on SPI analysis, 2013 and 2014 were contrasting years, 2013 was a severely dry year, whereas 2014 was moderately wet. Water level fluctuations were observed in the lake due to the differences in the water availability, with consequent changes in the recorded values of nutrients and conductivity, mainly in 2013 (Fig. 2). Coinciding with when the Water Authorities maintained the gates open, the water level was particularly high in the period from January to May and August to September for both years, the latter period being the greatest (Fig. 2a and b). Conductivity was high, with a mean value of $49.8 \mathrm{mS} \mathrm{cm}^{-1}$ during the study period, presenting a maximum in summer (February $2013=60.4 \mathrm{mS} \mathrm{cm}^{-1}$ ) and a minimum in spring (October $2013=41.1 \mathrm{mS} \mathrm{cm}^{-1}$ ) in response to the input of water and water level fluctuations $(r=-0.51 ; p<0.05$ and $r=-0.89 ; p<0.001$, respectively) (Fig. $2 \mathrm{a}$ and b). Additionally, nutrients presented higher concentrations during 2013 (Fig. 2c) coinciding with the larger input of water into the lake. Both variables were highly correlated $(r=0.53 ; p<0.01)$, TN varied between 3.3 (January 2014) and $16.3 \mathrm{mg} \mathrm{L}^{-1}$ (October 2014) and presented significant differences between years $(H=17.3 ; p<0.0001)$. TP fluctuated between 0.03 (July 2014) and $0.3 \mathrm{mg} \mathrm{L}^{-1}$ (July 2013) and was positively correlated with $\mathrm{TN}(r=0.68 ; p<0.0001)$. The TN/TP relationship was high (82.43) characterizing the lake as phosphorus limited.

The mean water temperature was $15.7^{\circ} \mathrm{C}$ and it displayed a seasonal pattern similar to the air temperature, ranging from 5.3 (June 2013) to $25.2^{\circ} \mathrm{C}$ (January 2014). Similarly, the mean air temperature was $15.3^{\circ} \mathrm{C}$ and it ranged from 6.4 (July 2013) to $22.9^{\circ} \mathrm{C}$ (January 2014). In winter of 2013 the mean air temperature $\left(8.7^{\circ} \mathrm{C}\right)$ was below the historical record $\left(9.6^{\circ} \mathrm{C}\right)$. High frequency measurements recorded air temperatures below $0^{\circ} \mathrm{C}$, generating a decrease in the mean water temperature values $\left(9.1^{\circ} \mathrm{C}\right)$ by air-water interaction processes. Transparency was high during the study period, with a mean SDD value of $159.3 \mathrm{~cm}$, ranging from 90 to $285 \mathrm{~cm}$. Seston values were low (mean value: $39.5 \mathrm{mg} \mathrm{L}^{-1}$ ) and ranged between 6 and $100.4 \mathrm{mg} \mathrm{L}^{-1}$. DO concentration presented a mean value of $10.1 \mathrm{mg} \mathrm{L}^{-1}$ and varied between 6.5 (February 2014) and $14.2 \mathrm{mg} \mathrm{L}^{-1}$ (June 2013), being negatively correlated with water temperature $(r=-0.6 ; p<0.01)$. The $\mathrm{pH}$ was always alkaline (8.05). Mean Chl $a$ was $9.3 \mu \mathrm{g} \mathrm{L}^{-1}$ and presented maximum values in autumn and winter, decreasing in the warmer period. Chl $a$ ranged from 1.26 (November 2013 ) to $18.15 \mu \mathrm{g} \mathrm{L}^{-1}$ (June 2013) being negatively correlated with the temperature $(r=-0.8 ; p<0.01$, Fig. 3$)$.

\subsection{Plankton communities}

The phytoplankton community found in La Salada comprised a total of 40 taxa including some species typical of saline lakes (Table S1, Supplementary Material). Phytoplankton abundances presented maximum values in autumn and winter and decreased towards summer, following seasonal temperature fluctuations. Abundances were dominated by small $(5-8 \mu \mathrm{m})$ chrysophytes from the genus Ochromonas Vysotskii, with abundances higher than $70 \%$ during all months. Maximum values were presented in winter (June 2013: 

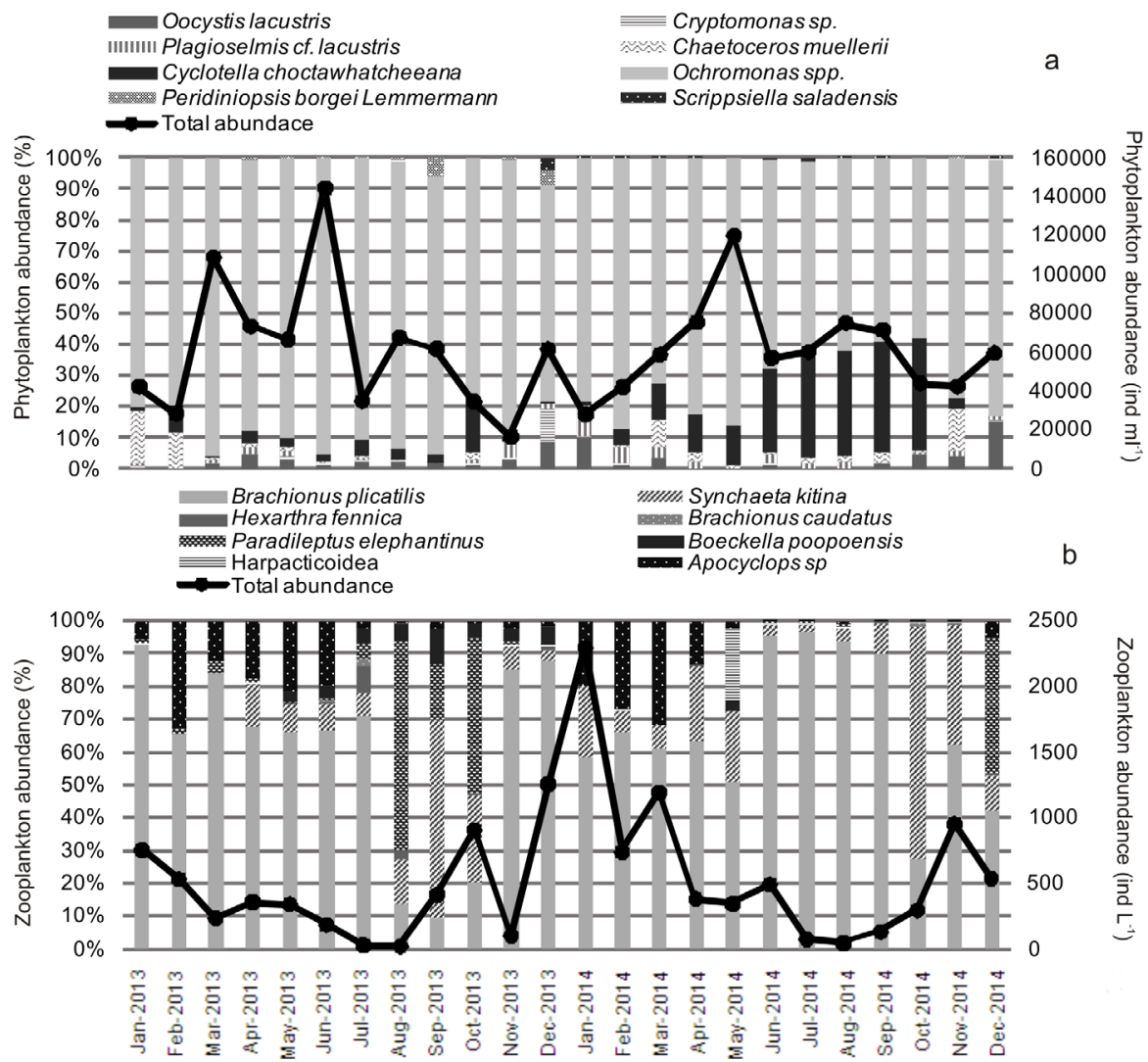

Fig. 3. Plankton abundances during the study period: (a) phytoplankton abundance (ind. $\mathrm{mL}^{-1}$ ) and (b) zooplankton abundance (ind. $\mathrm{L}^{-1}$ ).

150000 ind. $\mathrm{mL}^{-1}$ ) and minimum in spring (November 2013: 14082 ind. $\mathrm{mL}^{-1}$ ) (Fig. 3a). During the study period, the small diatom (8-10 $\mu \mathrm{m})$ Cyclotella choctawhatcheeana Prasad, was the second best represented, mainly during 2014 (Fig. 3a); it presented maximum values in September 2014 (25 117.03 ind. $\mathrm{mL}^{-1}$ ) and minimum in December 2013 (185.37 ind. $\mathrm{mL}^{-1}$ ). In the diatoms, the salinity tolerant Chaetoceros muelleri Lemmermann was present, but only during January 2013 and November 2014, being absent or depreciable for the rest of the study period. The dinoflagellates Peridiniopsis borgei Lemmermann and Scrippsella saladensis Balech and the genus Cryptomonas sp. were mainly present during 2013 (Fig. 3a). Cyanobacteria and Chlorophyta were occasional. Total phytoplankton biomass presented values between 3 and $25 \mathrm{mg} \mathrm{L}^{-1}$ (Fig. 4a), with the exception of December 2013 when a maximum of $60 \mathrm{mg} \mathrm{L}^{-1}$ was reached due to the presence of larger species, e.g. the dinoflagellates Peridiniopsis and Scrippsella and Cryptomonas sp. (Figs. 3a and 4a). During the rest of the study period, it was mainly represented by Ochromonas, except for 2014 when C. choctawhatcheeana was also dominant in the phytoplankton biomass (Fig. 4a).

The zooplankton community comprised a total of 14 taxa including species typical of saline lakes (Table S1, Supplementary Material). Zooplankton abundances did not present any significant differences between stations, so mean values were used for the analysis $(H=4.05 ; p>0.1)$. Maximum values were found in summer and the abundances decreased in winter, reaching values near to 0 ind. $\mathrm{L}^{-1}$ during winter of 2013 (Fig. $3 b)$. The zooplankton community was dominated by rotifers, with Brachionus plicatilis Müller as the main species, followed by Synchaeta kitina Rousselet (Fig. 3b). The remaining rotifer species occurred rather occasionally and were present in low abundances (Fig. 3b). B. plicatilis presented abundances ranging from 2.68 (August 2013) to 1344.8 ind. $\mathrm{L}^{-1}$ (January 2014) and S. kitina ranged from nil to 497.1 ind. $\mathrm{L}^{-1}$ (January 2014) (Fig. 3b). Copepod abundances were low in general (Fig. 4b), being mainly represented by one cyclopoid of the genus Apocyclops sp. and one calanoid Boeckella poopoensis Marsh. Harpacticoids were rather occasional. Apocyclops sp. ranged from nil (November 2014) to 382.1 ind. $\mathrm{L}^{-1}$ (March 2014) and presented maximum abundances in summer. B. poopoensis dominated in autumn and spring of 2013 and ranged from nil to 64.2 ind. $\mathrm{L}^{-1}$ (December 2013) during the study period (Fig. 3b). The large ciliate haptorid Paradileptus elephantinus Svec was mainly present from August to October 2013, reaching 430.68 ind. $\mathrm{L}^{-1}$ in October (Fig. 3b). Cladocerans were absent. Zooplankton biomass fluctuations were similar to the abundances, except for the spring of 2013 and summer 2014 (Figs. 3b and 4b). From August to October 2013, the biomass was exceptionally higher because of the presence of the large ciliate P. elephantinus (Fig. 4b). During the summer of 2014 the biomass was lower because it was mainly represented by the rotifers $B$. plicatilis and $S$. kitina (Fig. 4b). The total zooplankton biomass ranged from 0.005 (July 2013 ) to $0.47 \mathrm{mg} \mathrm{L}^{-1}$ (October 2013) (Fig. 4b).

\subsection{Relationship between plankton and environmental variables}

The biomass corresponded to the river Colorado water input (Figs. 4 and 5) according to the RDA analysis. The first 

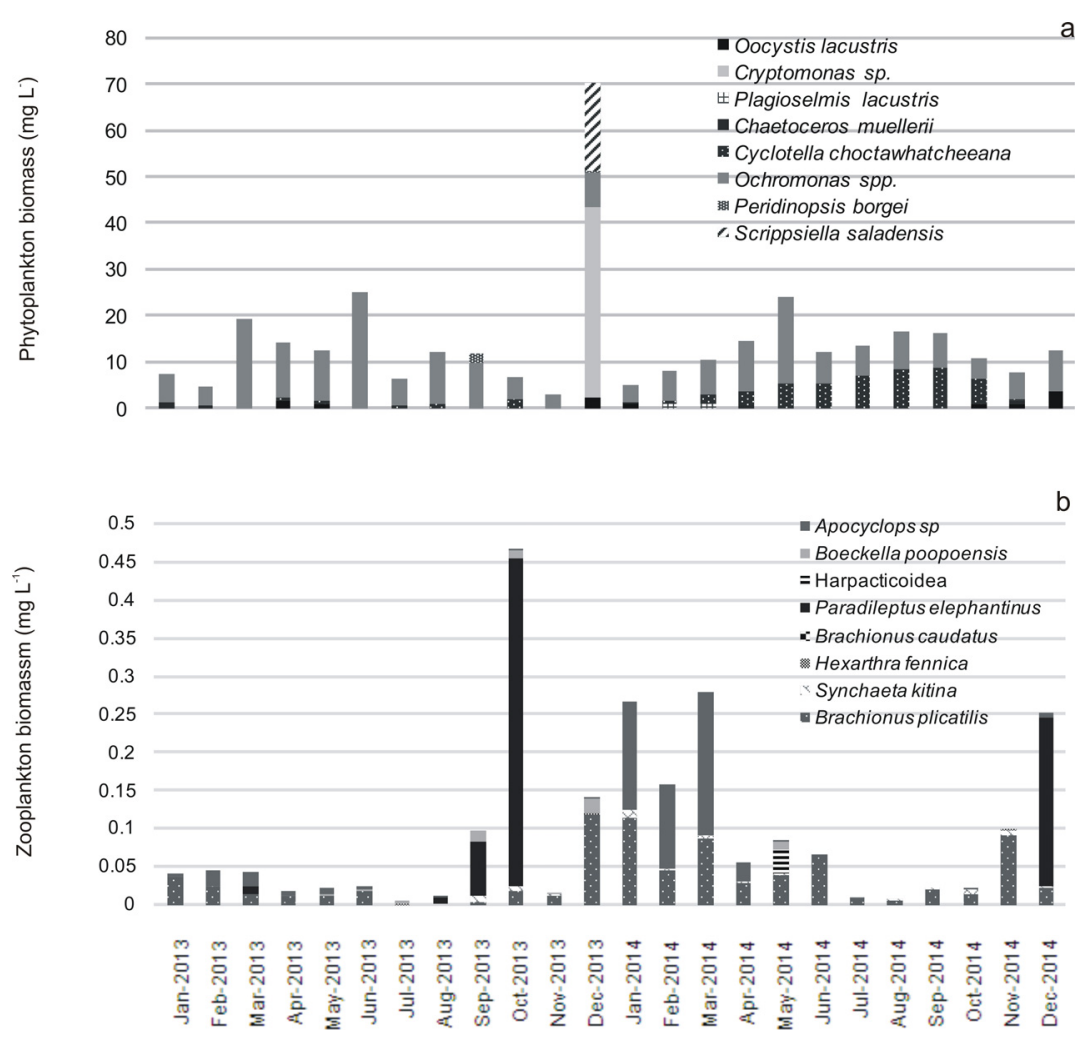

Fig. 4. Plankton biomass during the study period: (a) phytoplankton biomass $\left(\mathrm{mg} \mathrm{L}^{-1}\right)$ and (b) zooplankton biomass (mg $\left.\mathrm{L}^{-1}\right)$.

two axes accounted for $45 \%$ of total variance. Water input, conductivity, $\mathrm{TN}$ and temperature were the main explanatory variables (Fig. 5). This reflected a clear effect of water management during the study period, when the input of water and increase of nutrients from August to October produced a shift from rotifers to the ciliate $P$. elephantinus in the zooplankton. Then, when the zooplankton biomass decreased in November, the highest phytoplankton biomass was observed in December, with Cryptomonas sp. and $S$. saladensis as the main species. Also the species $B$. poopoensis and $P$. borgei were associated with high water level and water input values, whereas the halophile species $C$. muelleri and the cyclopoid Apocyclops sp. were associated with high conductivity values. Temperature explains the seasonal dynamics and it is the main explanatory variable (Fig. 5). The highest zooplankton biomass was recorded during summer, when conductivity reached maximum values (January to March), with the dominance of Apocyclops sp. and $B$. plicatilis as zooplankton associated with the presence of Plagioselmis lacustris and $C$. muelleri as phytoplankton. Autumn samples were characterized by the presence of Harpacticoid copepods, with the maximum biomass for Ochromonas spp. During winter, the diatom C. choctawhatcheeana mainly represented the phytoplankton community. Spring samples were characterized by the highest water input (and water level) and lowest conductivity, with the dominance of $S$. kitina and rare species, e.g. Hexarthra fennica and Brachionus caudatus in zooplankton. Also $P$. elephantinus showed a peak in December and in the phytoplankton the occurrence of the green algae Oocystis lacustris was characteristic.

\section{Discussion}

During the study period the Water Authorities allowed a large amount of water to enter the lake during 2013 (drought conditions) in order to maintain an acceptable water level and to avoid the lake reaching low water levels that probably would affect the development of tourist activities (aquatic sports, sport fishing, among others). Lakes in endorheic basins, such as La Salada, are particularly sensitive as they respond rapidly to drought/flood events due their shallow morphology (Starks et al., 2014). The observed input of water and the consequent water level fluctuations produced remarkable consecutive changes in conductivity and nutrient values, as was observed from the correlation analysis and the RDA. This was observed mainly in the period from August to September 2013, when the large amount of water entered the lake and greater changes were observed in nutrients and conductivity values (Fig. 2). These, in conjunction with seasonal temperature variations, shaped the plankton composition and dynamics in La Salada. The plankton community was characterized by small organisms and a low number of species, with a clear dominance of rotifers (B. plicatilis) and chrysophytas (Ochromonas spp.).

Plankton abundance and biomass dynamics showed different responses to the main physicochemical drivers. Abundance dynamics were driven by seasonal temperature fluctuations with, alternately, zooplankton in the warmer seasons and phytoplankton in the colder months. This is in contrast to other shallow lakes in the Pampas (Izaguirre et al., 2015), where phytoplankton blooms occurred mainly in spring and summer. The phytoplankton composition and abundance 


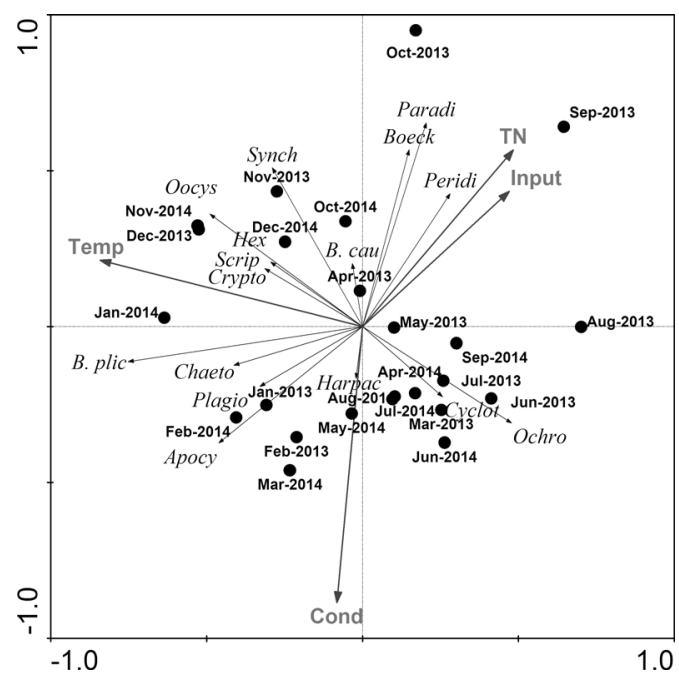

Fig. 5. Plot corresponding to RDA's (first and second axis) based on plankton biomass and main environmental variables during the study period. Abbreviations: Cond: conductivity, TN: total nitrogen, Temp: water temperature, Vol: cumulative volume, B. plic: B. plicatilis, Apocy: Apocyclops sp., Boeck: B. poopoensis, Harpac: Harpacticoidea, Hex: H. fennica, Synch: S. kitina, B. cau: B. caudatus, Parad: $P$. elephantinus, Ochro: Ochromonas spp., Chaeto: $C$. muelleri, Oocys: $O$. lacustris, Crypto: Cryptomonas sp., Scrip: S. saladensis, Plagio: $P$. lacustris, Cyclo: C. choctawhatcheeana, Peridi: P. borgei.

were similar to those reported for other saline lakes (Borics et al., 2012; Vignatti et al., 2012a). The phytoplankton community was dominated by the genus Ochromonas spp., often reported for cold environments, such as Patagonian lakes and Antartica, and with TP limiting conditions (Izaguirre et al., 2003). These features in conjunction with the low zooplankton abundances in winter months could explain the high abundances found for both years in winter. Also, it is well known that high alkalinity can also limit phytoplankton growth in saline lakes, which in turn results in low Chl $a$ concentrations and increased water transparency (Kopprio et al., 2014) as seen here. Chl a concentrations were comparable to concentrations expected for saline alkaline lakes (Evans and Prepas, 1997; Kopprio et al., 2014; Del Ponti et al., 2015). Salinity played an important role in shaping the plankton community towards more salt tolerant species and with a low species richness as found in other saline lakes (De los Ríos et al., 2005; Vignatti et al., 2012a; Starks et al., 2014). The zooplankton species association was similar to other saline lakes in the region (Echaniz and Vignatti, 2011; Echaniz et al., 2015). The dominance of rotifers and the fact that copepod abundances were low, being mainly represented by cyclopoids, is characteristic of eutrophic environments subject to a strong predation pressure by omnivore planktivore fish, e.g. Odonthesthes sp. (Iglesias et al., 2011; Vignatti et al., 2012b).

On the other hand, biomass dynamics were driven by the water input and the consecutive fluctuations in nutrients and conductivity, which were associated with the water management of the lake. These exceptional fluctuations in conjunction with temperature were reflected in the plankton biomass values. In 2013 the water input and the consequent increase of nutrients from August to October produced a shift from rotifers to the ciliate $P$. elephantinus reaching the highest zooplankton biomass values in October. This is in accordance with other studies in eutrophic and shallow lakes, such as Lake Võrtsjärv, where ciliates peaked in spring (Zingel and Nõges, 2010) and the highest biomass values were coupled with the occurrence of large ciliates, such as P. elephantinus. They found that the ciliates were clearly bottom up or controlled by food as in this case. It is well known that ciliate communities are very dynamic, and their community structure may respond quickly to changing physical, chemical and biological conditions in the environment (Jezbera et al., 2003). Modenutti and Pérez (2001) also found that the presence of this large ciliate was related to food conditions, feeding mainly on rotifers. Here we observed a clear decline in the B. plicatilis biomass and abundance, which clearly dominated the zooplankton composition during the rest of the study period. On the other hand, higher water input values in spring were associated with the appearance of $P$. borgei in phytoplankton and $B$. poopoensis with $P$. elephantinus in zooplankton. There is clear evidence that planktonic ciliates, e.g. P. elephantinus are an important food resource for large metazooplankton (Dolan and Coats, 1991; Gifford, 1991), e.g. B. poopoensis. In respect to the phytoplankton biomass, La Salada presented similar values to other saline lakes (Schagerl and Oduor, 2008) as well as with other clear lakes with similar TP concentrations (Izaguirre et al., 2012). When the zooplankton and phytoplankton biomass greatly decreased in November 2013, a peak in phytoplankton biomass was observed in December, with two of the larger phytoplankton species, Cryptomonas sp. and $S$. saladensis, as the main species. These species frequently increase in biomass when other populations are declining, exploiting the available temporary niche (Klaveness, 1988; Nedbalová et al., 2006). Therefore, Cryptomonas sp. and S. saladensis were able to quickly react to increased light and nutrient conditions.

The rest of the study period, biomass dynamics were ruled mainly by temperature variations. This determined an evident seasonal dynamic, with highest biomass and abundances in summer in zooplankton and in autumn and winter in phytoplankton. Summer samples were characterized by the higher conductivity and temperature values, with a species composition dominated by euryhaline species, e.g. B. plicatilis and Apocyclops sp. The autumn and winter months were dominated by the dominant species Ochromonas spp. and $C$. choctawhatcheeana. Both species are cited as having a preference for lower temperatures (Izaguirre et al., 2003; Burić et al., 2007). Spring samples presented the higher water input values associated with the occurrence of rare species, e.g. $H$. fennica and B. caudatus in zooplankton and O. lacustris in phytoplankton. In coincidence with these findings, $H$. fennica and $O$. lacustris were also cited for spring months (Echaniz et al., 2006; Kozak, 2009) and B. caudatus is associated with high water and low salinity values (Baloch et al., 2009; Brandorff et al., 2011).

In conclusion, major changes in nutrients and conductivity, in conjunction with the presence of fish, resulted in a plankton community of low diversity, characterized by halotolerant and small sized species, with characteristic changes in the plankton composition and biomass as a result of the water management. Although this time series is not long enough to define any trends, it allowed us to determine the consistent changes in the hydrological, physicochemical and biological variables for 
consideration in future water management in La Salada and other shallow saline lakes.

\section{Supplementary Material}

Table S1. List of phytoplankton and zooplankton species found in La Salada lake during the study period.

The Supplementary Material is available at https://www. limnology-journal.org/10.1051/limn/2017023.

Acknowledgements. We kindly thank Maximiliano García, Antonio Garayalde, Rosemary Scoffield and Federico Ferrelli, for their contributions, comments and suggestions with this paper. We also thank L. Lagomarsino, R. Escaray, and J. Bustingorry for nutrient analyses and Irina Izaguirre and Cristina Marinone for their valuable help in taxonomic determinations. Support for the studies dealing with the article was provided by grants from the network project $\mathrm{PAMPA}_{2}$ (CONICET), ANPCyT, Universidad Nacional del Sur (PGI 24/ G059) and the Inter American Institute for Global Change Research (IAI) CRN3038 (under US NSF Award GEO 1128040).

\section{References}

Alfonso MB, Vitale AJ, Menéndez MC, Perillo VL, Piccolo MC, Perillo GME. 2015. Estimation of ecosystem metabolism from diel oxygen technique in a saline shallow lake: La Salada (Argentina). Hydrobiologia 752: 223-237.

Aliaga VS, Ferrelli F, Piccolo MC. 2017. Regionalization of climate over the Argentine Pampas. Int J Climatol 37: 1237-1247.

APHA-AWWA-WPCF. 1998. Standard methods for the examination of water and wastewater. Washington, DC.

Baloch WA, Jafri SIH, Soomro AN. 2009. Occurrence of planktonic rotifer in Thar desert (Sindh, Pakistan). Transylv Rev Syst Ecol Res 8: 87.

Barker T, Hatton K, O'Connor M, Connor L, Bagnell L, Moss B. 2008. Control of ecosystem state in a shallow, brackish lake: implications for the conservation of stonewort communities. Aquat Conserv: Mar Freshw Ecosyst 18: 221-240.

Barnes BD, Wurtsbaugh WA. 2015. The effects of salinity on plankton and benthic communities in the Great Salt Lake, Utah, USA: a microcosm experiment. Can J Fish Aquat Sci 72: 807-817.

Beklioglu M, Romo S, Kagalou I, Quintana X, Bécares E. 2007. State of the art in the functioning of shallow Mediterranean lakes: workshop conclusions. Hydrobiologia 584: 317-326.

Bersain G. 2012. Laguna La Salada de Pedro Luro, Partido de Villarino. Campaña de relevamientos limnológicos e ictiológicos. Informe Técnico $\mathrm{N}^{\circ} 136$. Estación Hidrobiológica de Chascomús. Dirección de desarrollo de aguas continentales y acuicultura. Dirección provincial de pesca. Ministerio de Asuntos Agrarios. Ciudad de Buenos Aires, Buenos Aires, 20 p.

Bohn VY, Delgado AL, Piccolo MC, Perillo GM. 2016. Assessment of climate variability and land use effect on shallow lakes in temperate plains of Argentina. Environ Earth Sci 75: 1-15.

Borics G, Tóthmérész B, Lukács BA, Várbíró G. 2012. Functional groups of phytoplankton shaping diversity of shallow lake ecosystems. Hydrobiologia 698: 251-262.

Bottrell HH, Duncan A, Gliwicz ZM, Grygierek E, Herzig A, Hillbricht-Ilkowska A, Kurasawa H, Larsson P, Weglenska T. 1976. A review of some problems in zooplankton production studies. Norw J Zool 24: 419-456.
Brandorff GO, Pinto-Silva VA, Morini AA. 2011. Zooplankton: species diversity, abundance and community development. In: Junk WJ, Da Silva CJ, Nunes da Cunha C, Wantzen KM, eds. The Pantanal: ecology, biodiversity and sustainable management of a large neotropical seasonal wetland. Sofia, Moscow: Pensoft publishers, pp. 355-391.

Burić Z, Kiss KT, Ács E, Viličić D, Caput Mihalić K, Carić M. 2007. The occurrence and ecology of the centric diatom Cyclotella choctawhatcheeana Prasad in a Croatian estuary. Nova Hedwigia 84: 135-153.

Cassie R. 1971. Sampling and statistics. A manual on methods for the assessment of secondary productivity in fresh waters. IBP (International Biological Programme) Handbook. Oxford, England: Blackwell. Vol. 17, pp. 174-209.

Chaparro G, Fontanarrosa MS, O'Farrell I. 2016. Colonization and succession of zooplankton after a drought: influence of hydrology and free-floating plant dynamics in a floodplain lake. Wetlands 36: 85-100.

Debastiani-Júnior JR, Nogueira MG. 2016. How water level management affects cladoceran assemblages in lakes lateral to a reservoir. Mar Freshw Res 67: 1853-1861.

Del Ponti OD, Cabrera GC, Vignatti AM, Echaniz SA. 2015. Dynamics of the limnological parameters and zooplankton of $\mathrm{La}$ Brava, a shallow lake of the Atuel-Salado-Chadileuvú-Curacó Rivers system (La Pampa, Argentina). Appl Ecol Environ Sci 3: 193-199.

De los Ríos P. 2005. Richness and distribution of zooplanktonic crustacean species in Chilean Andes mountains and southern Patagonia shallow ponds. Pol J Environ Stud 14: 817-822.

Dolan JR, Coats DW. 1991. A study of feeding in predacious ciliates using prey ciliates labeled with fluorescent microspheres. J Plankton Res 13: 609-627.

Downing JA, Prairie Y, Cole JJ, Duarte CM, Tranvik LJ, Striegl RG, McDowell WH, Kortelainen P, Caraco NF, Melack JM, Middelburg JJ. 2006. The global abundance and size distribution of lakes, ponds, and impoundments. Limnol Oceanogr 51: 2388-2397.

Du J, Fang J, Xu W, Shi P. 2013. Analysis of dry/wet conditions using the standardized precipitation index and its potential usefulness for drought/flood monitoring in Hunan Province, China. Stoch Environ Res Risk Assess 27: 377-387.

Dumont HJ, Van de Velde I, Dumont S. 1975. The dry weight estimate of biomass in a selection of Cladocera, Copepoda and Rotifera from the plankton, periphyton and benthos of continental waters. Oecologia 19: 75-97.

Echaniz SA, Vignatti AM. 2011. Seasonal variation and influence of turbidity and salinity on the zooplankton of a saline lake in central Argentina. Lat Am J Aquat Res 39: 306-315.

Echaniz SA, Vignatti S, José de Paggi SJ, Paggi JC, Pilati A. 2006. Zooplankton seasonal abundance of south American saline shallow lakes. Int Rev Hydrobiol 91: 86-100.

Echaniz SA, Cabrera GC, Vignatti AM. 2015. Limnological parameters and population structure of Artemia persimilis Piccinelli and Prosdocimi, 1968 (Crustacea, Anostraca) in La Amarga, a Hypersaline Lake of La Pampa (Argentina). Res Zool 5: 25-31.

Evans JC, Prepas EE. 1997. Relative importance of iron and molybdenum in restricting phytoplankton biomass in high phosphorus saline lakes. Limnol Oceanogr 42: 461-472.

Gafny S, Gasith A. 1999. Spatially and temporally sporadic appearance of macrophytes in the littoral zone of Lake Kinneret, Israel: taking advantage of a window of opportunity. Aquat Bot 62: 249-267.

Gafny S, Gasith A, Goren M. 1992. Effect of water level fluctuation on shore spawning of Mirogrex terraesanctae (Steinitz), (Cyprinidae) in Lake Kinneret, Israel. J Fish Biol 41: 863-871. 
Gifford DJ. 1991. The Protozoan-Metazoan trophic link in pelagic ecosystems. J Protozool 38: 81-86.

Gleick P. 2003. Global fresh water resources: soft-path solutions for the 21st century. Science 302: 1524-1528.

Hillebrand H, Dürselen CD, Kirschtel D, Pollingher U, Zohary T. 1999. Biovolume calculation for pelagic and benthic microalgae. J Phycol 35: 403-424.

Iglesias C, Mazzeo N, Meerhoff M, Lacerot G, Clemente JM, Scasso F, Kurk C, Goyenola G, Garcia-Alonso J, Amsinck SL, Paggi JC, Paggi SJ, Jeppesen E. 2011. High predation is of key importance for dominance of small-bodied zooplankton in warm shallow lakes: evidence from lakes, fish exclosures and surface sediments. Hydrobiologia 667: 133-147.

IPCC. 2014. Synthesis report. Contribution of working groups I, II and III to the fifth assessment report of the intergovernmental panel on climate change. Switzerland: Geneva, $151 \mathrm{p}$.

Izaguirre I, Allende L, Marinone MC. 2003. Comparative study of the planktonic communities of three lakes of contrasting trophic status at Hope Bay (Antarctic Peninsula). J Plankton Res 25: 1079-1097.

Izaguirre I, Allende L, Escaray R, Bustingorry J, Pérez G, Tell G. 2012. Comparison of morpho-functional phytoplankton classifications in human-impacted shallow lakes with different stable states. Hydrobiologia 698: 203-216.

Izaguirre I, Sánchez ML, Schiaffino MR, O'Farrell I, Huber P, Ferrer N, Zunino J, Lagomarsino L, Mancini M. 2015. Which environmental factors trigger the dominance of phytoplankton species across a moisture gradient of shallow lakes? Hydrobiologia 752: 47-64.

Jeppesen E, Søndergaard M, Kanstrup E, Petersen B, Henriksen RB, Hammershøj M, Mortensen E, Jensen JP, Have A. 1994. Does the impact of nutrients on the biological structure and function of brackish and freshwater lakes differ? Hydrobiologia 275/276: 15-30.

Jeppesen E, Nõges P, Davidson TA, Haberman J, Nõges T, Blank K, Johansson LS. 2011. Zooplankton as indicators in lakes: a scientific-based plea for including zooplankton in the ecological quality assessment of lakes according to the European Water Framework Directive (WFD). Hydrobiologia 676: 279-297.

Jeppesen E, Brucet Balmaña S, Naselli-Flores L, Papastergiadou E, Stefanidis K, NogesT, Bucak T. 2015. Ecological impacts of global warming and water abstraction on lakes and reservoirs due to changes in water level and related changes in salinity. Hydrobiologia 750: 201-227.

Jezbera J, Nedoma J, Šimek K. 2003. Longitudinal changes in protistan bacterivory and bacterial production in two canyonshaped reservoirs of different trophic status. Hydrobiologia 504: 115-130.

Klaveness D. 1988. Ecology of the Cryptomonadida: a first review. In: Sandgren CD, ed. Growth and reproductive strategies of freshwater phytoplankton. Cambridge: Cambridge University Press, pp. 105-133.

Kopprio GA, Kattner G, Freije RH, de Paggi SJ, Lara RJ. 2014. Seasonal baseline of nutrients and stable isotopes in a saline lake of Argentina: biogeochemical processes and river runoff effects. Environ Monit Assess 186: 3139-3148.

Kozak A. 2009. Community structure and dynamics of phytoplankton in Lake Uzarzewskie. Teka Kom Ochr Kszt S rod Przyr - OL PAN 6: $146-152$.

Laas A, Nõges P, Kõiv T, Nõges T. 2012. High-frequency metabolism study in a large and shallow temperate lake reveals seasonal switching between net autotrophy and net heterotrophy. Hydrobiologia 694: 57-74.

Labraga J, Brandizi L, López M. 2011. Avances en el pronóstico climático de las anomalías de lluvia en la Región Pampeana. Meteorológica 36: 59-71.
Laird KR, Cumming BF. 2008. Reconstruction of Holocene lake level from diatoms, chrysophytes and organic matter in a drainage lake from the Experimental Lakes Area (northwestern Ontario, Canada). Quatern Res 69: 292-305.

Larson CA, Belovsky GE. 2013. Salinity and nutrients influence species richness and evenness of phytoplankton communities in microcosm experiments from Great Salt Lake, Utah, USA. J Plankton Res 35: 1154-1166.

Legendre P, Legendre L. 1998. Numerical ecology. Amsterdam: The Netherlands.

Leira M, Cantonati M. 2008. Effects of water-level fluctuations on lakes: an annotated bibliography. Hydrobiologia 613: 171-184.

Liu X, Qian K, Chen Y. 2015. Effects of water level fluctuations on phytoplankton in a Changjiang River floodplain lake (Poyang Lake): implications for dam operations. J Gt Lakes Res 41: 770-779.

Marker AFH, Crowther CA, Gunn RJM. 1980. Methanol and acetone as solvents for estimating chlorophyll a and phaeopigments by spectrophotometry. Arch Hydrobiol Beih Ergebn Limnol 14: 52-69.

Mirza MMQ. 2003. Climate change and extreme weather events: can developing countries adapt? Clim Policy 3: 233-248.

Modenutti BE, Pérez GL. 2001. Planktonic ciliates from an oligotrophic south Andean lake, Morenito lake (Patagonia, Argentina). Braz J Biol 61: 389-395.

Moos MT, Laird KR, Cumming BF. 2005. Diatom assemblages and water depth in Lake 239 (Experimental Lakes Area, Ontario): implications for paleoclimatic studies. J Paleolimnol 34: 217-227.

Nedbalová L, Stuchlík E, Strunecký O. 2006. Phytoplankton of a mountain lake (L'adové pleso, the Tatra Mountains, Slovakia): seasonal development and first indications of a response to decreased acid deposition. Biologia 61: 91-100.

Pilati A, Castellino M, Bucher EH. 2016. Nutrient, chlorophyll and zooplankton seasonal variations on the southern coast of a subtropical saline lake (Mar Chiquita, Córdoba, Argentina). Ann Limnol - Int J Limnol 52: 263-271.

Quirós R, Drago E. 1999. The environmental state of Argentinean lakes: an overview. Lakes Reserv: Res Manag 4: 55-64.

Rennella AM, Quirós R. 2006. The effects of hydrology on plankton biomass in shallow lakes of the Pampa Plain. Hydrobiologia 556: 181-191.

Schagerl M, Oduor SO. 2008. Phytoplankton community relationship to environmental variables in three Kenyan Rift Valley salinealkaline lakes. Mar Freshw Res 59: 125-136.

Scian B. 2000. Evidencias de la señal del SOI sobre la variabilidad de las lluvias en la Región Semiárida Pampeana. Meteorologica 35: 3-14.

Sparks RE, Nelson JC, Yin Y. 1998. Naturalization of the flood regime in regulated rivers. BioScience 48: 706-720.

Staehr PA, Bade D, Van de Bogert MC, Koch GR, Williamson C, Hanson P, Kratz T. 2010. Lake metabolism and the diel oxygen technique: state of the science. Limnol Oceanogr Methods 8: 628-644.

Starks E, Cooper R, Leavitt PR, Wissel B. 2014. Effects of drought and pluvial periods on fish and zooplankton communities in prairie lakes: systematic and asystematic responses. Glob Change Biol 20 : 1032-1042.

Stenger-Kovács C, Lengyel E, Buczkó K, Tóth MF, Crossetti OL. 2014. Vanishing world: alkaline, saline lakes in Central Europe and their diatom assemblages. Inland Waters 4: 383-396.

Sun J, Liu D. 2003. Geometric models for calculating cell biovolume and surface area for phytoplankton. J Plankton Res 25: 1331-1346.

Ter Braak CJ. 1986. Canonical correspondence analysis: a new eigenvector technique for multivariate direct gradient analysis. Ecology 67: 1167-1179. 
Utermöhl M. 1958. Zur Vervollkommnung der quantitativen Phytoplankton Methodik. Mitt Int Ver Limnol 9: 1-38.

Venrick EL. 1978. How many cells to count? In: Sournia A, ed. Phytoplankton manual. Paris: UNESCO, pp. 167-180.

Vignatti AM, Paggi JC, Cabrera GC, Echaniz SA. 2012a. Zooplankton diversity and its relationship with environmental changes after the filling of a temporary saline lake in the semi-arid region of La Pampa, Argentina. Lat Am J Aquat Res 40: 1005-1016.

Vignatti A, Cabrera G, Echaniz S. 2012b. Changes in the zooplankton and limnological variables of a temporary hypo-mesosaline wetland of the central region of Argentina during its drying Pan Am J Aquat Sci 7: 93-106.

Wolin JA, Stone JR. 2010. Diatoms as indicators of water-level change in freshwater lakes. In: Stoermer EF, Smol JP, eds. The diatoms: applications for the environmental and earth sciences. UK: Cambridge University Press, pp. 183-202.

Zingel P, Nõges T. 2010. Seasonal and annual population dynamics of ciliates in a shallow eutrophic lake. Fundam Appl Limnol: Arch Hydrobiol 176: 133-143.

Cite this article as: Alfonso MB, Zunino J, Piccolo MC. 2017. Impact of water input on plankton temporal dynamics from a managed shallow saline lake. Ann. Limnol. - Int. J. Lim. 53: 391-400 